\title{
Erratum to: Recognition of driving postures by combined features and random subspace ensemble of multilayer perceptron classifiers
}

C. H. Zhao $\cdot$ B. L. Zhang $\cdot$ X. Z. Zhang $\cdot$

S. Q. Zhao H. X. Li

Published online: 25 August 2012

(C) Springer-Verlag London Limited 2012

Erratum to: Neural Comput \& Applic

DOI 10.1007/s00521-012-1057-4

Unfortunately, the original version was published with incorrect author names. The correct author names are as follows:

C. H. Zhao, B. L. Zhang, X. Z. Zhang, S. Q. Zhao, H. X. Li

The online version of the original article can be found under doi:10.1007/s00521-012-1057-4.

C. H. Zhao ( $\square)$

College of Transportation, Southeast University,

Nanjing 210096, People's Republic of China

e-mail: chihangzhao@seu.edu.cn

B. L. Zhang

Department of Computer Science and Software Engineering,

Xi' an Jiaotong-Liverpool University, Suzhou 215123,

People's Republic of China

X. Z. Zhang · S. Q. Zhao · H. X. Li

Queensland Research Laboratory, National ICT Australia,

Brisbane, QLD 4111, Australia 